\title{
Empowerment of People with Disabilities in Surabaya City: A Study on Tiara Handicraft
}

\author{
RD Aparta ${ }^{1}$, E Setijaningrum ${ }^{2}$, R Rahardian ${ }^{3}$, MF Shodiq $^{4}$ \\ 1,2,3,4 Masters of Public Policy. Faculty of Social and Political Sciences. Universitas Airlangga, \\ Surabaya \\ ucokaparta71993@gmail.com ${ }^{1}$,erna.setijaningrum@,fisip.unair.ac.id ${ }^{2}$, ramaditya.rahardian- \\ 2018@,fisip.unair.ac.id ${ }^{3}$, fajrusshodiq@gmail.com ${ }^{4}$
}

\begin{abstract}
The limitations experienced by people with disabilities give rise to a negative selfimage in the community mindset. They are seen as weak and unproductive human beings. This condition causes difficulty for people with disabilities to find work to meet their needs. This study explores a microenterprise named Tiara Handicraft as an antithesis to the negative mindset to provide employment opportunities for people with disabilities. The method used in this study is qualitative research with data collection techniques including interviews and documentation. Finally, for data analysis, we use interactive analysis. The findings based on the field research show Tiara Handicraft as a textile and souvenir processing business that empowers people with disabilities as employees. The people with disabilities are empowered according to their potential and interests in a variety of positions ranging from production to marketing. The products produced have reached international markets such as America and Asia, which is evidence that the works of people with disabilities are indeed of high quality. Due to its commitment and success in empowering people with disabilities, Tiara Handicraft received various awards from various parties, both at the levels of national and abroad.
\end{abstract}

Keywords: Empowerment, People with Disabilities, Tiara Handicraft

\section{INTRODUCTION}

People with disabilities is one of the biggest minority group in the world. There are approximately 600 millions people and two thirds of them are in developing countries. At the beginning of the formation of the International Bill of Human Rights, it does not include people with disabilities as groups that are vulnerable to human rights violations[8]. The prevalence of persons with disabilities in Indonesia is classified very high. According to the University of Indonesia's Institute of Economic and Community Research (LPEM) in 2016, the estimated number of people with disabilities in Indonesia reached $12.15 \%$ of the total population or nearly 30 million people[17].

People with disabilities can be defined as individual who have limitations of physical, intellectual, mental, and/or sensory which can experience obstacles in interacting with the environment to the difficulty to participate fully and effectively with other citizens based on equal rights[16]. WHO defines people with disabilities as a restriction or inability to perform an activity in the manner or within the range considered normal for a human being, mostly resulting from impairment[4]. The definition clearly states that disability is a limitation or inability to carry out an activity in a manner within a range deemed normal to humans, in general due to 
decreased ability. Perople with disabilities can be classified into several types according to the barriers and limitations they experience, consisting of Blind, Deaf, Deaf, Deaf, Tunalaras (individual who has obstacles in controlling emotions and social control), Gifted Children, Autistic, ADHD, Learning Difficulties and Double Handicapt[11].

For many people in Indonesia, disabilities are seen as only individual's problem, due to the condition and thought[12]. People with disabilities are also classified as people with marginalized social welfare problems (PMKS). This perspective of society and the government which tend to discriminate against people with disabilities or disabilities have major implications for their difficulties in obtaining a decent life. Therefore, they are vulnerable to become victims of discrimination, marginalization, and exclusion in society, including in terms of work[3].

Everyone has the right to obtain decent work regardless of differences in economic, social, cultural and political status, both the majority and the minority or marginal[9]. However, today, due to the stigma and views of some companies thich consider people with disabilities are unable to work in accordance with company demands. They are often are only the second choice in work matters. It is believed that excluding persons with disabilities in the labor market can reduce the benefits resulting from economic activities. This belief raises awareness and an increasingly massive concern in various circles that if people with disabilities do not work ,then they will become an internal burden on the family and more broadly, of course they will also become a burden on the country.

One of alternatives in facing such marginalization is through empowerment efforts. The word Pemberdayaan 'Empowerment' is adopted from an English word translation, namely empowerment. It has the basic meaning of 'empowerment'/'pemberdayaan', 'power'/'daya' means power. According to the World Bank in Mardikanto (2010), empowerment is defined as an effort to provide opportunities and abilities to groups of people (poor) to be able and brave to voice (voice) or voice their opinions, ideas, and ideas, as well as the ability and courage to choose (choice) something (concepts, methods, products, actions, etc.) that are best for the person, family and society[5]. Empowerment refers to the ability of people who are weak and disadvantaged (disadvantaged groups). Thus they can have strength or ability in several ways[13]. Mardikanto (2010) states that community empowerment is a process of support so that people, especially those who have limited resources, women and other neglected groups, are able to improve their welfare independently[5]. Sulistyani (2017) states the goal to be achieved from empowerment is to make individuals and the community independent. This independence includes the independence of thinking, acting and controlling what they do. To achieve community independence a gradual learning process is needed in order to gain abilities. Thus, adequate capacity will accumulate to deliver community to be independence as a goal of empowerment[14].

Empowerment idea in disabilities group is a central aspect for a strategy to obtain social justice and human rights, even though empowerment is a word which has been overused in a language that loses its substantive meaning[15]. In addition, community development aims to increase the empowerment of those who are disadvantaged[15]. Empowerment can be understood as a form of radical change, which will bring down the structures and discourses of domination. Empowerment can also help create more socially equitable communities, as well as empowerment for local community members who will strengthen the community and enable the creation of a more effective community-based structure[15].

Some previous researches also showed that the idea of empowerment becomes an alternative for a disability group in obtaining proper work rights, see in [1] who seek to see a disability empowerment that leads to piloting by the Regional Personnel Agency in enhancing 
an independence. Second, it is a study from[2] which seeks to see welfare empowerment efforts in Karangpahitan village, Ponorogo district. The concept of empowerment becomes an alternative when the government which in its capacity makes a policy is not able to satisfy certain groups[10], especially minority groups from disabilities. This paper aims to see how a concept of empowerment can be beneficial for disability groups amidst the high stigma of society and companies which do not want to be open to disability groups in terms of work

\section{RESEARCH METHOD}

This This research was qualitative research with descriptive above to see disabilities based people's empowerment. According to Denzin and Lincoln in Moleong (1994: 5), qualitative research is "research which uses a natural setting to interpret phenomena that occur and it is carried out by involving various existing methods [7]. "One of the uses of qualitative research is to produce a description and analysis of important activities, processes or events. The research location is in the "Tiara Handicraft" institute in Surabaya. Data collection techniques were carried out by interview and documentation. We determined the informants with a purposive sampling technique. The informants in this research were the owners and managers of the "Tiara Handicraft" institution and some of its employees who are empowered disability groups. Finally, to analyze the data of this research we use interactive analysis by following the guidelines of (Miles, MB, Huberman, AM, \& Saldaña, 2014) which include: Gathering news and data, conducting condensation of research findings, displaying research data and draw a conclusion at the end [6].

\section{RESULTS AND DISCUSSION}

\section{Initial Condition}

At first, Tiara Handicraft was founded not to empower peope with disabilities. However, in 1999 during the monetary crisis, Tiara Handicraft leaders had thought to close this business because of limited human resources. At that time, the employees who mostly came from out of town decided to return to their hometowns. In the midst of the situation, there was a friend of the owner of Tiara Handicraft who suggested employing people with disabilities. They had doubts because hiring people with disabilities would not be the same as hiring normal people. At first, Tiara Handicraft tried to recruit two people, one with a leg amputation, one hand and one arm only. For a person who had leg amputations, he did not have significant obstacles in working, but a person with only one hand had obstacles because the majority of us have jobs such as sewing, of course, he has difficulty. Yet, we tried to adjust to the conditions of employees. We realize that every person with a disability cannot be treated the same. We began to give job desks according to their conditions and abilities.

\section{Empowerment and Network formation}

Tiara handicraft was founded in 1995. 1999 is a turning point of handicraft tiara to start collaborating with disabilities people. Starting from these two people, Tiara Handicraft tried to explore and decided to recruit peoplewith disabilities. In 1999, the concept carried was to provide work opportunities for them even though it was not one hundred percent because we also recruited teenagers who had dropped out of school. It started with 5 people with disabilities and 11 teenagers dropping out of school. Furthermore, in 2003 ,Tiara Handicraft began to collaborate with the Social Forces Development Institution (PSBD), DEAKSES Solo, the Vocational Rehabilitation Center for Persons with Disabilities in Cibinong. From the various 
stakeholders, finally more people with disabilities entered to work at Tiara Handicraft with soft skills which they obtained from various organizations and institutions.

Until 2006, in collaboration with 63 people, around 80 percent were people with disabilities. People with disabilities received are even more uniform starting from orthopedically handicapped, deaf until there are two blind people. In 2007, it began to think again why only accept people with disabilities who already have soft skills, then what about people with disabilities who have never received more job training out there. With this in mind, Tiara Handicraft began to develop to open up full access for all people with disabilities both those who have work skills and those who have not. For persons with disabilities who already have the basic ability to work, they are given the opportunity to adapt and choose themselves to work in what parts according to their interests and abilities.

Many people with disabilities working at Tiara Handicraft makes some Local government officials question and dispute the legal aspects of us in empowering people with disabilities. Furthermore, in 2009 we formed the Bina Karya Tiara Foundation to overshadow its social functions. Through the Bina Karya Tiarainilah Foundation, we finally tried to provide various training for persons with disabilities who do not yet have the skills or soft skills to work. The large number of people with disabilities who joined us both from the city of Surabaya and outside the region encouraged Tiara Handicraft to evolve into a business in which all employees consisted of people with disabilities. In 2014, when Ms. Khofifah became social minister, Tiara Handicraft was named as a company which employed 100 percent of people with disabilities. Thus, if it is not disabled, it is not acceptable and the only condition to be accepted to work at Tiara Handicraft is to have a disability.

\section{The Achievement and Independence}

Various product of handicraft made by people with disabilities at Tiara Handicraft are bags, clothes, various batik, tissue boxes, tablecloths, pillows,dolls and others. In terms of quality, the products produced by Tiara Handicraft are not inferior, even classified as high quality when compared to manufactured products. Therefore, for self-marketing, Tiara Handicraft often obtains orders from many parties, both individually and in the community, not only from the city of Surabaya, but many also order from outside the city and even outside the province. the Tiara Handicraft market currently has even penetrated the international market to America and several Asian countries. This is inseparable from the efforts made by Tiara Handicraft owners and people with disabilities who actively promote their products at various events and exhibitions held by the city government of Surabaya and East Java province.

\section{Figure 1}

Tiara Handicraft Group

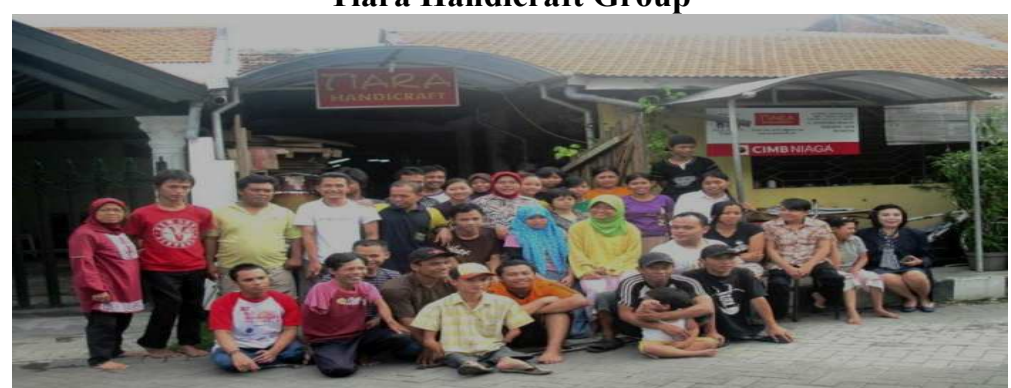

Source: instagram of Tiara Handicraft, 2018

Total of active employee with disabilities at Tiara Handicraft are 23 people because Tiara Handicraft does not bind them to the the contract and gives them the freedom to determine their way of life. Even Tiara Handicraft encourages people with disabilities who have experience 
working to return to their area and open their own businesses with the expectation of opening new jobs in their area for the general public especially for other disabled people who are in their areas. Tiara Handicraft has never received assistance from the government except the opportunity to take part in exhibitions, so this is a purely private business. In addition to providing employment and income opportunities for people with disabilities, Tiara Handicraft also certainly benefits from this business. Based on the results of the Tiara Handicraft monthly financial statements, the turnover obtained ranges from 25-35 million rupiahs per month. Actually, we also have the desire to open a new Tiara handicraft in other areas so that more people with disabilities can be empowered. However, to find people who are highly committed to empowering people with disabilities is not easy.there are people who have managed to open their own businesses and improve their economies.

Due to her persistence and consistency in empowering people with disabilities, the owner of Tiara Titik Winarti handicraft received an award from the President of the Republic of Indonesia in 2009. In addition, this woman of three children also had the opportunity to speak at the annual meeting of the United Nations (UN) which took place in New York., United States of America. He also had the opportunity to attend a brief training on social projects for three weeks in America.

Figure 2

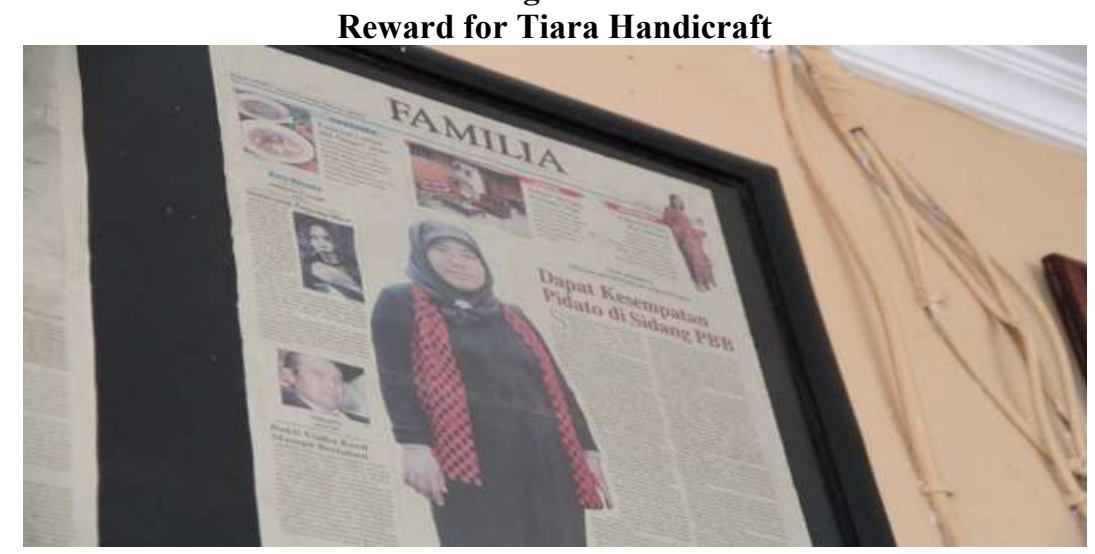

Source: instragram of Tiara Handicraft, 2019

\section{CONCLUSIONS}

Concept of empowerment can become an alternative in the middle of community stigma and companies in seeing disability groups who are always marginalized. Tiara Handicraft Surabaya succeeded in building an empowerment of people with disabilities in obtaining employment rights in a sustainable manner. Besides, the independence of this group of people with disabilities is successfully built by Tiara Handicraft in employing persons with disabilities in the city of Surabaya without financial assistance from the government. Finally, connections have also been created for people with disabilities

\section{REFERENCES}


[1] Aminah, S., Suprihatiningrum, J., \& Hanjarwati, A. (2015). PRODADISA "Program Pemberdayaan Difabel Daksa" menuju Percontohan BKD (Balai Kerja Difabel) untuk Meningkatkan Kemandirian dan Life Skill Difabel. Inklusi, 2(2), 299. https://doi.org/10.14421/ijds.2209

[2] Andriana, L. (2017). Kesejahteraan Sosial Tunagrahita di Ponorogo. Inklusi, 4(1), 25. https://doi.org/10.14421/ijds.040102

[3] Ardiyantika, S. (2016). Strategi Advokasi Perempuan Difabel Korban Kekerasan di SAPDA. Inklusi, 3(2), 193. https://doi.org/10.14421/ijds.030203

[4] Barbotte, E.Guillemin, F.Chau, N. Lorhandicap Group, 2011, Prevalence of Impairments, Disabilities, Handicaps and Quality of Life in the General Population: A Review of Recent Literature, Bulletin of the World Health Organization, Vol.79, No. 11, p. 1047

[5] Mardikanto. 2010. Konsep-konsep Pemberdayaan Masyarakat. Surakarta : UNS Press

[6] Miles, M. B., Huberman, A. M., \& Saldaña, J. (2014). Qualitative Data Analysis: A Methods Sourcebook

[7] Moleong, L.J. (1994). Metode Penelitian Kualitatif. Bandung: Remaja Rosda Karya

[8] Nursyamsiah, Fajri, et al. Kerangka Hukum Disabilitas di Indonesia : Menuju Indonesia Ramah Disabilitas. Jakarta: Pusat Studi Hukum dan Kebijakan Indonesia, 2016

[9] Poerwanti, S. D. (2017). Pengelolaan Tenaga Kerja Difabel untuk Mewujudkan Workplace Inclusion. Inklusi, 4(1), 1. https://doi.org/10.14421/ijds 040101

[10] Rahardian, R., \& Haryanti, R. H. (2018). Evaluating The Use of Paralegal Approach in Policy Advocacy, 22(1), 14-19. Retrieved from https://journal.ugm.ac.id/jkap

[11] Rachmayana, Dadan (2013) Diantara Pendidikan Luar Biasa Menuju Anak Masa Depan yang Inklusif. Jakarta: PT. Luxima Metro Media

[12] Salim, I. (2016). Perspektif Disabilitas dalam Pemilu 2014 dan Kontribusi Gerakan Difabel Indonesia bagi Terbangunnya Pemilu Inklusif di Indonesia. ,. The POLITICS : Jurnal Magister Ilmu Politik Universitas Hasanuddin, 1(2), 127-156

[13] Suharto, Edi. 2009. Membangun Masyarakat Memberdayakan Masyarakat. (Bandung: PT Refika Aditama)

[14] Sulistyani, A.T. 2017. Kemitraan dan Model-Model Pemberdayaan. Yogyakarta : Gava Media

[15] Tesorieoro., I. \&. (2016). Community Development: Alternatif Pengembangan Masyarakat di Era Globalisasi. Yogyakarta: Pustaka Pelajar

[16] Undang-Undang RI No. 8 Tahun 2016 Tentang Penyandang Disabilitas

[17] https://www.lpem.org/wp-content/uploads/2016/12/Lembar-fakta-rev5.pdf 